\title{
Geographic trends in range sizes explain patterns in bird responses to urbanization in Europe
}

${ }^{1}$ E. Adyho 1,985 31

Rapovce, Slovak Republic Corresponding author, E-mail: ferenc.michal85@gmail.com

${ }^{2}$ Department of Ecology, Faculty of Science, Charles University, Viničná 7, 12844 Praha 2, Czech Republic

${ }^{3}$ Department of Zoology, Faculty of Science, Charles University, Viničná 7, 12844 Praha 2, Czech Republic

${ }^{4}$ Department of Zoology, Faculty of Science, University of South Bohemia Branišovská 31, 37005 České Budějovice, Czech Republic

${ }^{5}$ Università degli Studi di Napoli "Federico II", Dipartimento di Agraria Via Università 100, 80055 Portici, NA, Italy

${ }^{6}$ Center for Theoretical Study, Charles University and Czech Academy of Sciences, Jilská 1, 11000 Praha 1, Czech Republic

\section{INTRODUCTION}

Urbanization is a process substantially transforming the original environment and its impacts are perceivable at all spatial scales (Seto et al., 2012; Grimm et al., 2015). Urbanized areas act as systematic environmental filters leading to the most significant ecological impact of urbanization, documented especially on avian communities, called biotic homogenization (Jokimäki \& Kaisanlahti-Jokimäki, 2003; Clergeau et al., 2006; McKinney, 2006; Luck \& Smallbone, 2011; Ferenc et al., 2014a; Sol et al., 2014; Morelli et al., 2016; Leveau et al., 2017). It is exemplified by higher avifaunal similarity among corresponding parts of the urbanization gradient of different cities than among different parts of the urbanization gradient within particular cities (Clergeau et al., 2001, 2006), or by higher similarity among cities than among their species pools (Luck \& Smallbone, 2011; Ferenc et al., 2014a). The latter example represents a large scale homogenizing effect and is apparently stronger at higher latitudes of Europe. However, this pattern is paradoxically a consequence of proportionally more species from particular regional assemblages entering European cities at higher latitudes (Ferenc et al., 2014a). The question therefore is: i) what makes these cities of higher latitudes more attractive to birds, or ii) what makes birds of higher latitudes more predisposed to persist in cities in comparison to south European species?

External factors might include differences in climate along the latitudinal gradient. Positive effects of urbanization due to greater food availability and predictability throughout the year (Jokimäki \& Suhonen, 1993) might be more pronounced at higher latitudes, thereby making urban areas more attractive to birds in this region. Alternatively, differences in history of urbanization at different latitudes of Europe (Jokimäki et al., 2016b) might be reflected in the degree of original habitat alteration in urban areas, and thus, in their suitability and attractivity to birds (Evans et al., 2009).

On the other hand, particular bird traits also show latitudinal patterns (Cardillo, 2002) and many studies pointed 
to ecological, behavioural or life-history traits that enable or prevent them to persist in cities (e.g., Bonier et al., 2007; Kark et al., 2007; Croci et al., 2008; Hu \& Cardoso, 2009; Conole \& Kirkpatrick, 2011; Evans et al., 2011; Díaz et al., 2013; Sol, 2013; Leveau, 2013; Meffert \& Dziock, 2013; Cardoso, 2014; Sol et al., 2014; Jokimäki et al., 2016a). Recently, it has been shown that commonness (i.e., geographic range or total population size) is a strong predictor of affinity of European bird species to towns and cities (Ferenc et al., 2018). Birds' range sizes vary in space (Orme et al., 2006) and species of higher latitudes tend to have larger ranges (Rapoport, 1982; Stevens, 1989; Cardillo, 2002). This so called Rapoport's rule holds quite well at least at the northern hemisphere (Rohde, 1996; Gaston et al., 1998), and it might affect bird responses to urbanization across latitudes in Europe.

The aim of this study was to reveal whether external factors make European cities of higher latitudes more attractive to birds or whether the assumed latitudinal trend in range sizes drives the observed patterns in proportions of species of regional assemblages occurring in cities (proportional richness hereafter). In order to do so, using two datasets on the European breeding avifauna of entire cities and city core zones, we tested the following hypotheses: i) Geographical position (especially latitude) has an independent effect on the proportional richness of birds, which might indicate a role of various factors correlated with geographical gradients, such as climate or urbanization history. ii) Patterns of habitat availability and/ or habitat heterogeneity within cities of Europe drive the spatially structured differences in proportional richness of their avifaunas. iii) The proportional richness of cities is linked to the
Rapoport's rule predicting a latitudinal increase in range sizes of species of particular regional bird assemblages.

\section{MATERIALS AND METHODS}

\subsection{Data collection}

Data on breeding bird communities in a) 41 European cities (Fig. 1) were extracted from the urban bird atlases (atlas dataset); and b) 37 European city core zones (core zone dataset) were obtained from a dataset published by Jokimäki et al. (2016a, 2016b). St. Petersburg was excluded from this dataset due to incomplete data on its regional bird assemblage (see definition below). All non-natives were removed from the atlas dataset. The core zone dataset contained two non-native species (Psittacula krameri, Alopochen aegyptiaca), but their inclusion is highly unlikely to substantially influence the results. The atlas dataset contained species with possible, probable and confirmed breeding status to minimize inconsistencies due to different assignment of species into these categories across particular atlases. On the other hand, the core zone dataset contained only species with probable or confirmed breeding status (Jokimäki et al., 2016a). The composition and richness of regional bird assemblages was retrieved from the EBCC Atlas of European Breeding Birds (Hagemeijer \& Blair, 1997). The regional avifauna of each city was defined as the bird assemblage of nine - if available - atlas grid cells (cell size: 50 by $50 \mathrm{~km}$ ) surrounding each city. The central square included the city or most of the city area and the remaining eight squares surrounded the central square. The proportion of species from

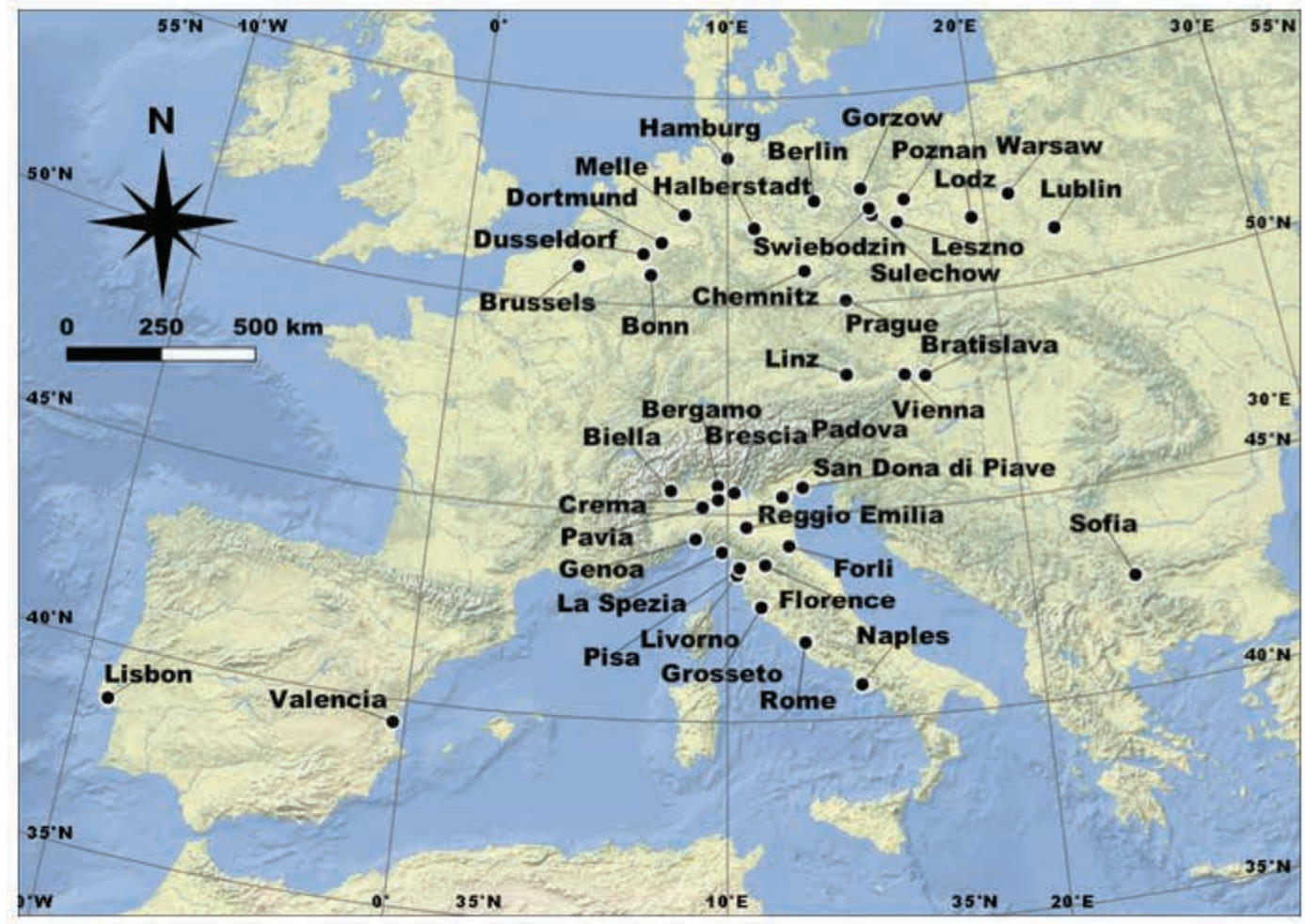

Figure 1. Geographical distribution of the European cities in the 'atlas dataset' 
each regional assemblage occupying the corresponding city or city core zone was used as the response variable (see also Table S1 in Appendix S1 and Jokimäki et al., 2016a, 2016b).

In the atlas dataset, the city area was either directly extracted from a particular atlas or calculated as the product of the number of its grid cells and the size of a single cell. While relying on particular authors' expertise in city border definition, only atlases with comparable methodology were utilized (see, e.g., Dinetti et al., 1995). For example, the atlas of Paris was excluded as it covered only the inner-city and not the entire city area (Malher et al., 2010). In the core zone dataset, only the innermost historical city centres were included and their area recorded (Jokimäki et al., 2016a). Furthermore, the proportion of i) 'vegetated', ii) 'built-up' and iii) 'other' land cover was recorded for each city (Ferenc et al., 2014a; Jokimäki et al., 2016a) and the Shannon index (Shannon's H) reflecting their habitat heterogeneity was calculated thereof (Shannon, 1948). Finally, we recorded the European breeding range size (i.e., the number of occupied grid cells of the EBCC atlas); latitudinal range extent in Europe (i.e., the number grid cells between the northernmost and southernmost location of occurrence in the EBCC atlas); and the global range size (BirdLife International, 2018) for each bird species.

\subsection{Data analysis}

Subsequently, we constructed generalized linear models (with quasibinomial error distribution due to overdispersion and the logit-link function) to relate the proportional richness to the predictor set. In the case of the atlas dataset, both city area and time span of data collection of urban bird atlases influence the recorded species richness, and consequently, the proportional richness of each city. Therefore, these two variables were included in all models to account for their effects. Similarly, for the core zone dataset, all models contained the study plot area. These models were regarded as the baseline models.

A full model containing latitude, longitude, proportion of vegetated area, Shannon index of habitat heterogeneity and either mean European range size (MERS hereafter) or mean latitudinal extent in Europe or mean global range size of birds in particular regional assemblages was created. Thereaf-

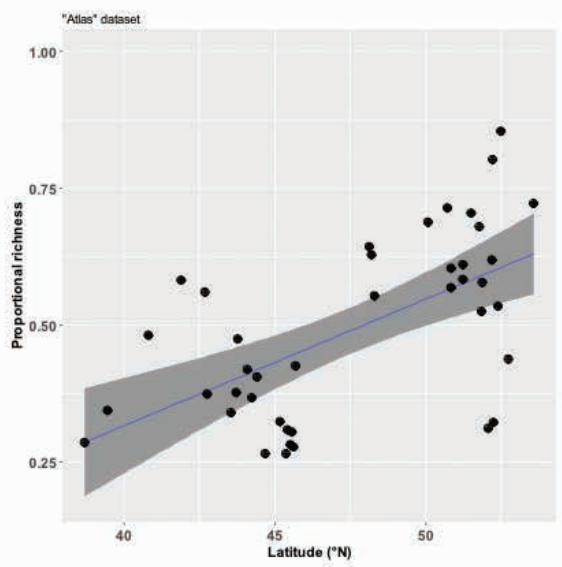

ter, we constructed the minimal adequate models by backward elimination of predictors while retaining only those causing a significant increase in residual deviance when removed. Finally, we tested for the presence of residual autocorrelation in the resulting models using Moran's I.

To test whether bird species present in cities are nonrandomly selected from regional assemblages according to their range sizes, we performed a randomization test for the atlas dataset. We randomly selected from each regional bird assemblage the same number of species as was actually present in the corresponding city. This procedure was repeated 10,000-times and we recorded the proportion of MERS, mean latitudinal extent and mean global range size of randomized the communities that were smaller than those observed in cities.

All analyses were carried out in R (R Core Team, 2017) using the following packages: 'tidyverse' (Wickham, 2017) for data manipulation and plotting, 'fields' (Nychka et al., 2017) for geographical distance calculation and 'ape' (Paradis et al., 2004) for Moran's I calculation.

\section{RESULTS}

The first premise of this study was an increasing proportional richness of urban avifauna with increasing latitude: although such a latitudinal trend of proportional richness was detected in the case of the atlas dataset $\left(R^{2}{ }_{A D J}=0.34, p<0.001\right.$; Fig. 2a) this relationship did not hold for the birds of city core zones $\left(R^{2}{ }_{A D J}=0.00, p=0.36\right.$; Fig. $\left.2 b\right)$. The second premise of increasing geographical ranges or extent of species with latitude held in dependence on the utilized measure: the MERS of urban birds showed an increasing latitudinal trend in the case of the atlas dataset $\left(R_{A D J}^{2}=0.42, p<0.001\right.$; Fig. S3.1a in Appendix S3), while this pattern was reversed at higher European latitudes as the core-zone dataset revealed $\left(R^{2}{ }_{A D J}=0.43, p<0.001\right.$; Fig. S3.1b in Appendix S3). The pattern was very similar for the mean latitudinal extent of species in regional assemblages (atlas dataset: $\mathrm{R}_{\mathrm{ADJ}}=0.88, \mathrm{p}<0.001$; Fig. S3.2a in Appendix S3; core zone dataset: $\mathrm{R}_{\text {ADJ }}^{2}=0.83, \mathrm{p}<0.001$; Fig. S3.2b in Appendix S3). In contrast, the mean global range sizes of species

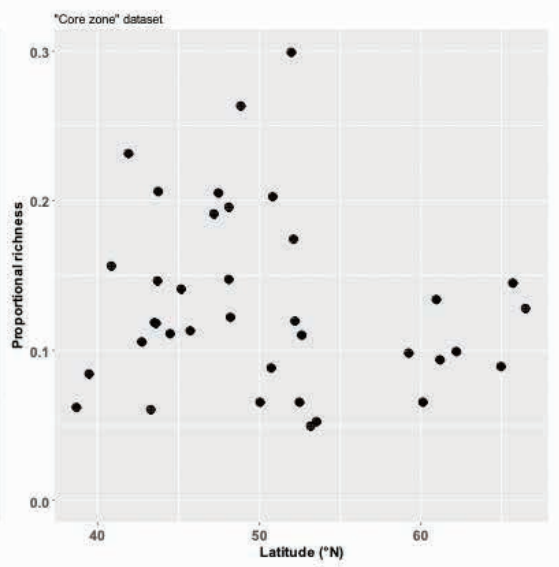

Figure 2. Relationship between the proportional richness of European urban avifaunas (a) atlas dataset $\left(R^{2}=0.34, p<0.001\right)$; $b$ ) core zone dataset $\left.\left(R_{A D J}^{2}=-0.004, p=0.36\right)\right)$ plotted against latitude. The trend was fitted by OLS regression, shaded areas depict $95 \%$ confidence intervals. 

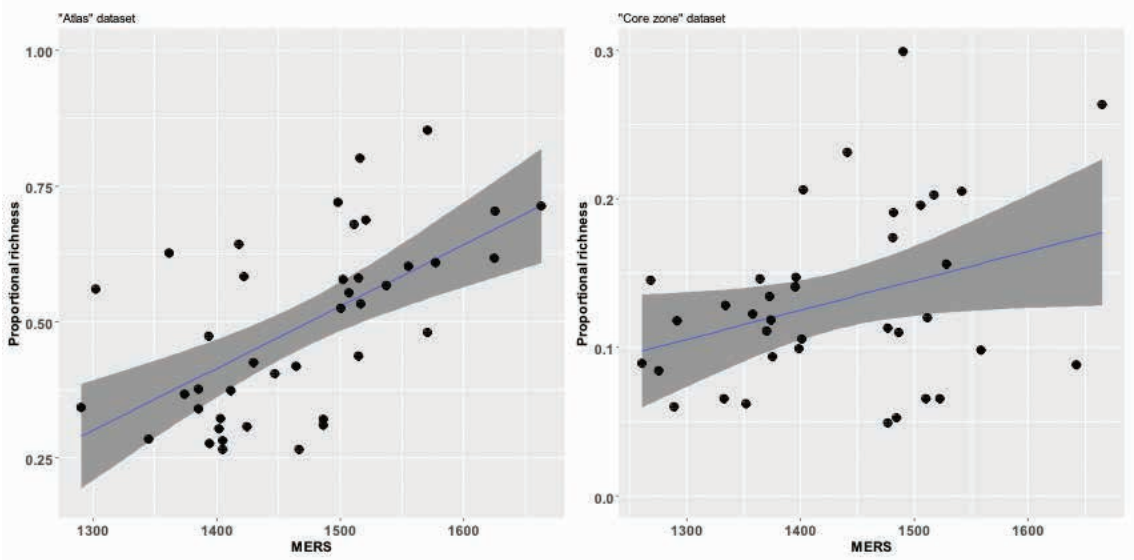

Figure 3. Relationship between the proportional richness of European urban avifaunas (a) atlas dataset $(R 2 A D J=0.34, p<0.001)$; $b)$ core zone dataset (R2ADJ $=0.08, p<0.001)$ ) plotted against the mean European range size (MERS; based on the number of occupied EBCC atlas grid cells) of species of particular regional assemblages. The trend was fitted by OLS regression, shaded areas depict 95\% confidence intervals.

in regional assemblages increased with latitude consistently in both datasets (atlas dataset: $\mathrm{R}_{\mathrm{ADJ}}^{2}=0.34, \mathrm{p}<0.001$; Fig. S3.3a in Appendix S3; core zone dataset: $\mathrm{R}^{2}{ }_{\mathrm{ADJ}}=0.81, \mathrm{p}<0.001$; Fig. S3.3b in Appendix S3).

Our results lend support to our central hypothesis: the model for all species in the atlas dataset revealed (Table 1; Table S2.1 in Appendix S2) that spatial position represented by latitude $(0.033 \pm 0.014, t=2.32, p<0.05)$ and longitude $(0.02$ $\pm 0.008, t=2.56, p<0.05)$ as well as MERS of species in the regional assemblages $(0.0017 \pm 0.0007, t=2.48, p<0.05$; Fig. 3a) had a significant positive effects on the proportional richness of birds in European cities. On the other hand, only MERS $(0.0017$ $\pm 0.0008, \mathrm{t}=2.04, \mathrm{p}<0.05$; Fig. $3 \mathrm{~b}$ ) had an influence on the proportional richness of birds in the core zones of the European cities. If the model included the mean latitudinal extent of species in regional assemblages, it was significant $(0.18 \pm 0.03, \mathrm{t}=$ $5.87, p<0.001)$ along with longitude $(0.02 \pm 0.007, t=2.43, p<$ 0.05 ) in the case of the atlas dataset (Table 1; Table S2.1 in Appendix S2; Fig. S3.4a in Appendix S3;). However, no model could be built upon our predictors in the case of the core zone dataset (Table 1; Table S2.1 in Appendix S2; Fig. S3.4b in Appendix S3;). Similarly, when including the mean global range sizes of birds in regional assemblages, only latitude had a significant positive effect $(0.07 \pm 0.01, t=2.32, p<0.001)$ on the proportional richness of birds in the case of the atlas dataset (Table 1; Table S2.1 in Appendix S2; Fig. S3.4a in Appendix S3) and no model could be constructed for the core zone dataset (Table 1; Table S2.1 in Appendix S2; Fig. S3.4b in Appendix S3). None of the resulting models showed any residual autocorrelation at the $5 \%$ significance level.

Due to the strong correlation between latitude and mean global range size of birds in regional assemblages, we conducted additional post-hoc analyses. They showed that if the initial full model for the atlas dataset included either of the range size descriptors (MERS, mean latitudinal extent or mean global range size), but not latitude, the range size descriptor was always retained in the final model. The same was true for latitude, when leaving out the range size descriptors from the

Table 1: Simplified representation of models constructed by backward elimination showing significant predictors (at the 5\% significance level) of proportional richness of urban avifaunas in European cities (atlas dataset) and city core zones (core zones dataset) and their effect (' + ' indicates a positive effect). Shaded columns represent different measures of mean geographic range sizes of birds in particular regional assemblages (see Methods for definitions)

\begin{tabular}{|c|c|c|c|c|c|}
\hline Dataset & $\begin{array}{l}\text { mean European } \\
\text { range size }\end{array}$ & latitude & longitude & Shannon's H & $\begin{array}{c}\% \text { vegetation } \\
\text { cover }\end{array}$ \\
\hline core zones & + & & & & \\
\hline Dataset & $\begin{array}{c}\text { mean latitudinal } \\
\text { extent }\end{array}$ & latitude & longitude & Shannon's H & $\%$ vegetation cover \\
\hline atlas & + & & + & & \\
\hline \multicolumn{6}{|l|}{ core zones } \\
\hline Dataset & $\begin{array}{c}\text { mean global range } \\
\text { size }\end{array}$ & latitude & longitude & Shannon's H & $\%$ vegetation cover \\
\hline atlas & & + & & & \\
\hline core zones & & & & & \\
\hline
\end{tabular}


initial full model. On the other hand, no such effect was revealed in the case of the core zone dataset (results not shown).

The role of range sizes of birds in determining their proportional richness in cities was further emphasized by the randomization test using the atlas dataset, as the observed urban assemblages had significantly higher MERS than would be expected by chance at the $5 \%$ significance level. Similar results were obtained by analysing latitudinal extents of birds, although there were two cities where the avifauna had mean latitudinal extents as if they were randomly assembled from the regional assemblages. However, with using global range sizes, only seven out of 41 cities had avifaunas with higher mean global range sizes than would be expected by chance, while the rest of the cities had mean global range sizes as if the urban avifaunas were assembled randomly.

\section{DISCUSSION}

Urban avifaunas of European cities and city centres seem to be influenced by both their spatial position at the continent per se as well as by the range sizes of species representing the potential species pool in particular regions. Although we detected no influence of vegetation availability or habitat heterogeneity on the proportional richness of urban avifaunas, the effect of geographic location might indicate an influence of unmeasured external factors that are linked to spatial position, such as climatic conditions. On the other hand, features of bird species also influence the richness of urban avifaunas, with relatively more species entering cities in regions occupied by more widespread species.

Cities located towards the north-east of continental Europe (based on the atlas dataset excluding Nordic countries) with relatively continental climate tend to host higher proportions of birds from regional assemblages. Such patterns might be related to the climate moderating effects of urban areas due to the heat-island phenomenon (Erz, 1966; Arnfield, 2003) resulting in greater availability of food resources during the critical periods and their better predictability throughout the year (Jokimäki \& Suhonen, 1993). Such effects might enhance the habituation and establishment of populations of particular species within cities (Møller et al., 2014; Tryjanowski et al., 2015). However, the pattern of increasing proportional richness of birds did not hold for the northernmost city core zones (based on the core zone dataset) with the harshest climate, which makes this interpretation dubious. Furthermore, urbanization at higher latitudes of Europe is a relatively recent phenomenon (Jokimäki et al., 2016b) and the responses of bird species might be delayed. That means that avifaunas of different regions have had unequal amount of time to respond to urbanization by adaptation or by going extinct (Essl et al., 2015). The city-age effect can go both ways: i) younger cities can have higher proportional richness as some species (e.g., forest specialists) will still go extinct in the future or ii) younger cities can have lower proportional richness due to less time for adaptation. Again, the fact that the Nordic cities are the youngest, but do not have the highest proportional richness, disfavours the first explanation, but not the second one. Nevertheless, the discrepancy among the two datasets showing an increase in proportional richness with latitude in the case of entire cities, but no such pattern in the case of city core zones, could partly arise because of their different scales of observation. The possibly positive effects of urbanization observable at the scale of entire cities (such as the heat-island phenomenon [Erz, 1966; Arnfield, 2003]) might be overridden by its negative impacts in the most urbanized city core zones (Clergeau et al., 2006).

Surprisingly, neither the proportion of vegetation cover nor the habitat heterogeneity played any role in determining the proportional richness of urban avifaunas. This points to the fact that although such factors are of prominent importance in determining bird species richness of urban communities at smaller scales (Evans et al., 2009; Ferenc et al., 2014b, 2016), their importance is not necessarily detectable at large spatial scales (MacGregor-Fors et al., 2010). Instead, spatial patterns of species range sizes seem to be a substantial part of the explanation although our initial hypothesis of the link between Rapoport's rule (Rapoport, 1982; Stevens, 1989) and bird responses to urbanization does not hold. We found some evidence in favour of the influence of MERS and mean latitudinal extent, for which Rapoport's rule does not hold, but limited evidence in favour of global range sizes, for which the Rapoport's rule does hold. On the one hand, the link between MERS and proportional richness of cities persisted regardless of whether we focused on entire cities or on city core zones including Nordic cities. On the other hand, the latitudinal extent showed an influence only in the case of entire cities, while not in the case of city core zones. And finally, global range sizes showed no influence in either case. As shown by the randomization tests for MERS or mean latitudinal extent, the urban assemblages systematically filter widespread species, but the evidence is much weaker if considering mean global range sizes. However, even under this scenario, urban avifaunas never showed smaller mean range sizes than the randomly selected assemblages. The discrepant results for MERS or mean latitudinal extent versus mean global range sizes might have two very different reasons: i) the strong correlation between latitude and global range size might lead to a situation when these two variables mask each-others influence on proportional richness. Indeed, the post-hoc analyses revealed such an effect and the mean global range size was always present in the final model if latitude was omitted from the initial full model (and vice-versa), at least in the case of the atlas dataset. ii) The shape of ranges of many northern bird species might be elongated in the west-east direction across Eurasia, but they might be relatively narrow in the north-south direction. Such species might in some ways experience less variable environments than species having global ranges more elongated in the north-south direction, but this would require further testing, which is out of scope of this study.

Indeed, the ability of species to cope with variable environmental conditions and its link to their geographic range sizes might be behind the observed relationships (Stevens, 
1989). Widespread birds might have high environmental tolerance possibly due to their ecological, behavioural or physiological flexibility, which can be beneficial under urban conditions (Bonier et al., 2007). Traits of widespread species thus might be directly beneficial for survival in cities or indirectly connected to urbanization by influencing the commonness of species (Ferenc et al., 2018). Less common birds might simply be extinction-prone in urban areas or less likely to colonize them (Sol et al., 2014). Alternatively, species with larger ranges tend to be more numerous locally (Brown, 1995, 2013; Gaston et al., 2000; Gaston \& Blackburn, 2008), which can enhance their occurrence in cities due to mass effects (Shmida \& Wilson, 1985), favourable metapopulation dynamics (Brown \& Kodric-Brown, 1977; Hanski, 1995) or by lowering their local extinction risk (Purvis et al., 2000).

Evidence of the influence of species' commonness on their occurrence in towns and cities is accumulating (Dale et al., 2015; Jokimäki et al., 2016b; Ferenc et al., 2018). Our findings have some important implications for assessing the ecological impacts of urbanization on birds in different geographic locations. Geographical regions showing apparent compositional uniformity of urban bird assemblages are not necessarily the ones most negatively impacted by urbanization (Ferenc et al., 2014a). Based on our results, we have to take into account geographic location, the geographically changing patterns of range sizes of birds and the enhanced potential of more widespread species to persist in towns and cities. In a similar vein, the urban filter is not necessarily more permeable in regions showing greater distinctness of urban avifaunas. The growth of cities thus poses a greater threat to the bird assemblages in regions composed of less widespread species having a weaker ability to respond to the challenges of urbanization.

\section{ACKNOWLEDGEMENTS}

We would like to thank all the ornithologists and birdwatchers who participated in the data collection for 41 urban bird atlases in Europe. We also wish to thank Marco Dinetti for providing part of the data and Martina Komínová for digitizing a substantial part of the data. In memoriam, many thanks to Vojtěch Jarošík, who was very inspiring during the early phases of this work.

\section{REFERENCES}

Arnfield A.J. (2003) Two decades of urban climate research: a review of turbulence, exchanges of energy and water, and the urban heat island. International Journal of Climatology, 23, 1-26.

BirdLife International (2018) Available at: http://www.birdlife.org.

Bonier F., Martin P.R., \& Wingfield J.C. (2007) Urban birds have broader environmental tolerance. Biology Letters, 3, 670-673.

Brown J.H. (1995) Macroecology. University of Chicago Press,

Brown J.H. (2013) On the relationship between abundance and distribution of species. The American Naturalist, 124, 255-279.

Brown J.H. \& Kodric-Brown A. (1977) Turnover Rates in Insular Biogeography: Effect of Immigration on Extinction. Ecology, 58, 445-449.

Cardillo M. (2002) The life-history basis of latitudinal diversity gradients: how do species traits vary from the poles to the equator? Journal of Animal Ecology, 71, 79-87.

Cardoso G.C. (2014) Nesting and acoustic ecology, but not phylogeny, influence passerine urban tolerance. Global Change Biology, 20, 803-810.

Clergeau P., Croci S., Jokimäki J., Kaisanlahti-Jokimäki M.-L., \& Dinetti M. (2006) Avifauna homogenization by urbanisation: analysis at different European latitudes. Biological Conservation, 127, 336-344.

Clergeau P., Jokimäki J., \& Savard J.P.L. (2001) Are urban bird communities influenced by the bird diversity of adjacent landscapes? Journal of Applied Ecology, 38, 1122-1134.

Conole L.E. \& Kirkpatrick J.B. (2011) Functional and spatial differentiation of urban bird assemblages\rat the landscape scale. Landscape and Urban Planning, 100, 11-23.
Croci S., Butet A., \& Clergeau P. (2008) Does Urbanization Filter Birds on the Basis of Their Biological Traits? The Condor, 110, 223-240.

Dale S., Lifjeld J.T., \& Rowe M. (2015) Commonness and ecology, but not bigger brains, predict urban living in birds. BMC Ecology, 15, 12.

Díaz M., Møller A.P., Flensted-Jensen E., Grim T., Ibáñez-Álamo J.D., Jokimäki J., Markó G., \& Tryjanowski P. (2013) The Geography of Fear: A Latitudinal Gradient in Anti-Predator Escape Distances of Birds across Europe. PLoS ONE, 8, e64634.

Dinetti M., Cignini B., Fraissinet M., \& Zapparoli M. (1995) Gruppo di lavoro 'Atlanti ornitologici urbani italiani': standard per le ricerche sull'Avifauna di ambienti urbanizzati'. Rivista italiana di Ornitologia, 64, 141-149.

Erz W. (1966) Ecological principles in the urbanization of birds. Ostrich, 37, 357-363.

Essl F., Dullinger S., Rabitsch W., Hulme P.E., Pyšek P., Wilson J.R.U., \& Richardson D.M. (2015) Delayed biodiversity change: no time to waste. Trends in Ecology \& Evolution, 30, 375-378.

Evans K.L., Chamberlain D.E., Hatchwell B.J., Gregory R.D., \& Gaston K.J. (2011) What makes an urban bird? Global Change Biology, $17,32-44$

Evans K.L., Newson S.E., \& Gaston K.J. (2009) Habitat influences on urban avian assemblages. Ibis, 151, .

Ferenc M., Sedláček O., Fuchs R., Dinetti M., Fraissinet M., \& Storch D. (2014a) Are cities different? Patterns of species richness and beta diversity of urban bird communities and regional species assemblages in Europe. Global Ecology and Biogeography, 23, 479-489. 
Ferenc M., Sedláček O., \& Fuchs R. (2014b) How to improve urban greenspace for woodland birds: site and local-scale determinants of bird species richness. Urban Ecosystems, 17, 625-640.

Ferenc M., Sedláček O., Fuchs R., Hořák D., Storchová L., Fraissinet M., \& Storch D. (2018) Large-scale commonness is the best predictor of bird species presence in European cities. Urban Ecosystems, 21, 369-377.

Ferenc M., Sedláček O., Mourková J., Exnerová A., Škopek J., Formánek J., \& Fuchs R. (2016) Disentangling the influences of habitat availability, heterogeneity and spatial position on the species richness and rarity of urban bird communities in a central European city. Urban Ecosystems, 19, 1265-1281.

Gaston K. \& Blackburn T. (2008) Pattern and Process in Macroecology (Google eBook). Blackwell Science, Oxford,

Gaston K.J., Blackburn T.M., Greenwood J.J.D., Gregory R.D., Quinn R.M., \& Lawton J.H. (2000) Abundance-occupancy relationships. Journal of Applied Ecology, 37, 39-59.

Gaston K.J., Blackburn T.M., \& Spicer J.I. (1998) Rapoport's rule: time for an epitaph? Trends in Ecology \& Evolution, 13, 70-74.

Grimm N.B., Faeth S.H., Golubiewski N.E., Redman C.L., Wu J., Bai X., Briggs J.M., Grimm N.B., Faeth S.H., Golubiewski N.E., Redman C.L., Wu J., Bal X., \& Briggs J.M. (2015) Global Change and the Ecology of Cities Global Change and the Ecology of Cities. Science, 319, 756-760.

Hagemeijer W. \& Blair M. (1997) The EBCC Atlas of European Breeding Birds. Poyser, London,

Hanski I. (1995) Metapopulation Dynamics. Population (English Edition), 396, 41-49.

Hu Y. \& Cardoso G.C. (2009) Are bird species that vocalize at higher frequencies preadapted to inhabit noisy urban areas? Behavioral Ecology, 20, 1268-1273.

Jokimäki J. \& Kaisanlahti-Jokimäki M.L. (2003) Spatial similarity of urban bird communities: A multiscale approach. Journal of Biogeography, 30, 1183-1193.

Jokimäki J. \& Suhonen J. (1993) Effects of urbanization on the breeding bird species richness in Finland: a biogeographical comparison.

Jokimäki J., Suhonen J., Jokimäki-Kaisanlahti M.L., \& Carbó-Ramírez P. (2016a) Effects of urbanization on breeding birds in European towns: Impacts of species traits. Urban Ecosystems, 19, 15651577.

Jokimäki J., Suhonen J., \& Kaisanlahti-Jokimäki M.-L. (2016b) Urbanization and species occupancy frequency distribution patterns in core zone areas of European towns. European Journal of Ecology, 2, 23-43.

Kark S., Iwaniuk A., Schalimtzek A., \& Banker E. (2007) Living in the city: Can anyone become an "urban exploiter"? Journal of Biogeography, 34, 638-651.

Leveau L.M. (2013) Bird traits in urban-rural gradients: how many functional groups are there? Journal of Ornithology, 154, 655-662.

Leveau L.M., Jokimäki J., \& Kaisanlahti-Jokimäki M.-L. (2017) Scale dependence of biotic homogenisation by urbanisation: a comparison of urban bird communities between central Argentina and northern Finland. European Journal of Ecology, 3, 1-18.
Luck G.W. \& Smallbone L.T. (2011) The impact of urbanization on taxonomic and functional similarity among bird communities. Journal of Biogeography, 38, 894-906.

MacGregor-Fors I., Morales-Pérez L., \& Schondube J.E. (2010) Does size really matter? Species-area relationships in human settlements. Diversity and Distributions, 17, 112-121.

Malher F., Lesaffre G., Zucca M., \& Coatmeur J. (2010) Oiseaux nicheurs de Paris. Un atlas urbain. Paris: Corif. Delachaux et Niestlé, .

McKinney M.L. (2006) Urbanization as a major cause of biotic homogenization. Biological Conservation, 127, 247-260.

Meffert P.J. \& Dziock F. (2013) The influence of urbanisation on diversity and trait composition of birds. Landscape Ecology, 28, 943-957.

Møller A.P., Jokimäki J., Skorka P., \& Tryjanowski P. (2014) Loss of migration and urbanization in birds: a case study of the blackbird (Turdus merula). Oecologia, 175, 1019-1027.

Morelli F., Benedetti Y., Ibáñez-Álamo J.D., Jokimäki J., Mänd R., Tryjanowski P., \& Møller A.P. (2016) Evidence of evolutionary homogenization of bird communities in urban environments across Europe. Global Ecology and Biogeography, 25, 1284-1293.

Nychka D., Furrer R., Paige J., \& Sain S. (2017) fields: Tools for spatial data. .

Orme C.D.L., Davies R.G., Olson V.A., Thomas G.H., Ding T.S., Rasmussen P.C., Ridgely R.S., Stattersfield A.J., Bennett P.M., Owens I.P.F., \& others (2006) Global patterns of geographic range size in birds. PLoS Biology, 4, e208.

Paradis E., Claude J., \& Strimmer K. (2004) A\{PE\}: analyses of phylogenetics and evolution in $\{R\}$ language. Bioinformatics, 20, 289290.

Purvis A., Gittleman J.L., Cowlishaw G., \& Mace G.M. (2000) Predicting extinction risk in declining species. Proceedings of the Royal Society B: Biological Sciences, 267, 1947-1952.

R Core Team (2017) R: A Language and Environment for Statistical Computing. .

Rapoport E.H. (1982) Areography: Geografical Strategies of Species. Pergamon Press Oxford,

Rohde K. (1996) Rapoport's Rule is a Local Phenomenon and Cannot Explain Latitudinal Gradients in Species Diversity. Biodiversity Letters, 3, 10.

Seto K.C., Guneralp B., \& Hutyra L.R. (2012) Global forecasts of urban expansion to 2030 and direct impacts on biodiversity and carbon pools. Proceedings of the National Academy of Sciences, 109, 16083-16088.

Shannon C.E. (1948) A Mathematical Theory of Communication. Bell System Technical Journal, 27, 379-423.

Shmida A. \& Wilson M. V. (1985) Biological Determinants of Species Diversity. Journal of Biogeography, 12, 1.

Sol D. (2013) Behavioural adjustments for a life in the city. Animal Behaviour, 85, 1101-1112.

Sol D., González-Lagos C., Moreira D., Maspons J., \& Lapiedra O. (2014) Urbanisation tolerance and the loss of avian diversity. Ecology Letters, 17, 942-950.

Stevens G.C. (1989) The Latitudinal Gradient in Geographical Range: How so Many Species Coexist in the Tropics. The American Naturalist, 133, 240-256. 
Tryjanowski P., Skórka P., Sparks T.H., Biaduń W., Brauze T., Hetmański T., Martyka Rafałand Indykiewicz P., Myczko Ł., Kunysz P., Kawa P., Czyż S., Czechowski Pawełand Polakowski M.Z.P., Jerzak L., Janiszewski T., Goławski A., Duduś L., Nowakowski J.J., Wuczyński A., \& Wysocki D. (2015) Urban and rural habitats differ in number and type of bird feeders and in bird species consuming supplementary food. Environmental Science and Pollution Research, 22, 15097-15103.

Wickham H. (2017) tidyverse: Easily Install and Load the 'Tidyverse'. 


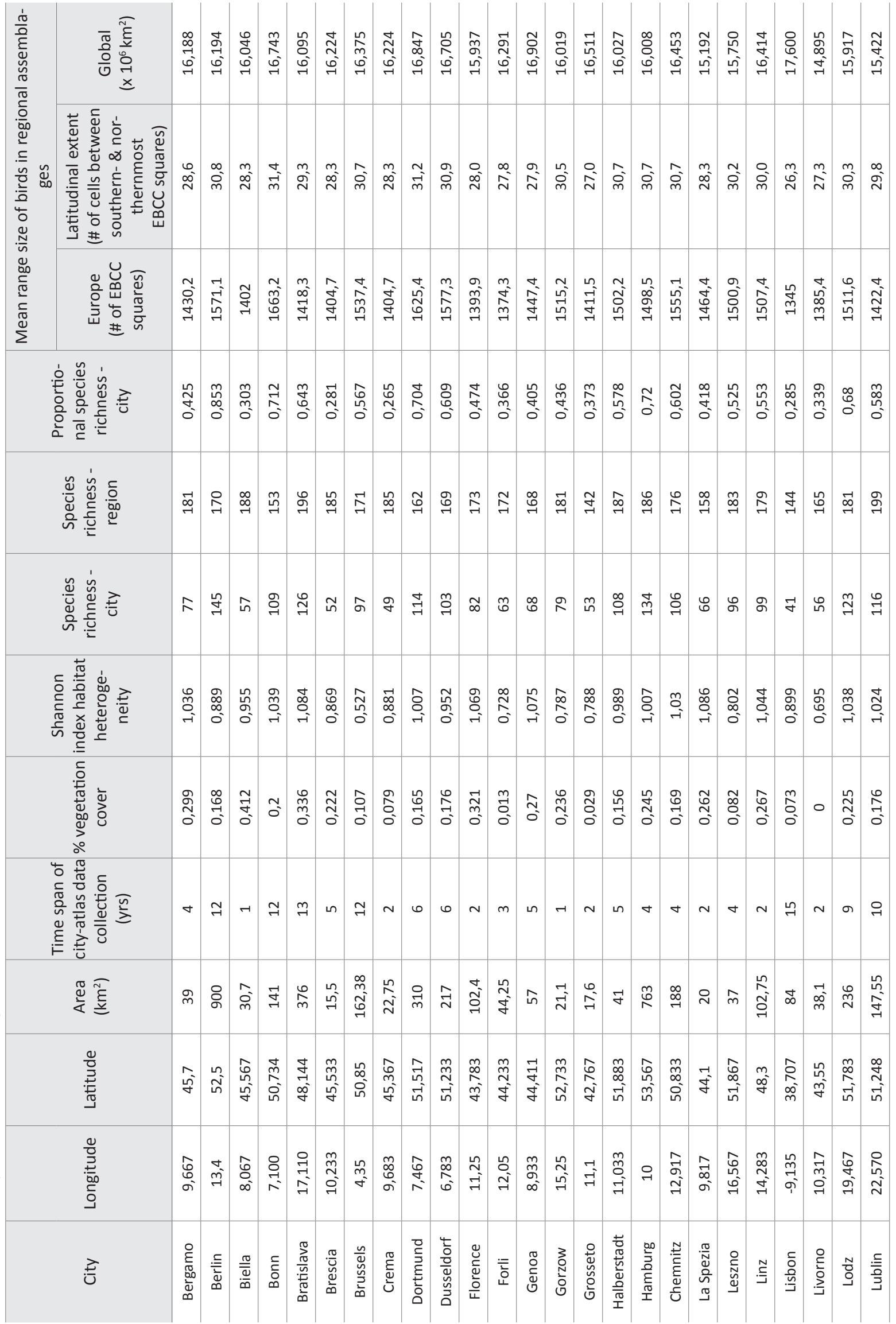




\begin{tabular}{|c|c|c|c|c|c|c|c|c|c|c|c|c|c|c|c|c|c|}
\hline 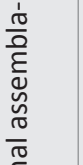 & 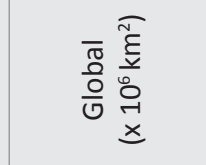 & $\begin{array}{l}\tilde{0} \\
0 \\
0 \\
0 \\
-1\end{array}$ & 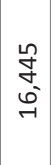 & $\begin{array}{l}\mathbf{0} \\
8 \\
0 \\
0\end{array}$ & $\begin{array}{l}\text { on } \\
\text { ț } \\
\text { - }\end{array}$ & \begin{tabular}{l} 
足 \\
$\infty$ \\
\multirow{-}{*}{}
\end{tabular} & 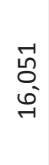 & $\begin{array}{l}2 \\
0 \\
0 \\
0 \\
-1\end{array}$ & 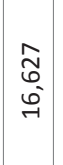 & 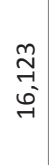 & $\begin{array}{l}\hat{n} \\
\hat{n} \\
\\
\end{array}$ & $\begin{array}{l}0 \\
0 \\
\infty \\
\text { ch }\end{array}$ & $\begin{array}{l}\tilde{0} \\
0 \\
\omega \\
n\end{array}$ & $\begin{array}{l}\tilde{0} \\
\infty \\
\text { जิ }\end{array}$ & 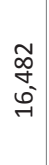 & 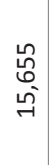 & 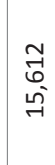 \\
\hline 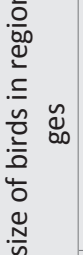 & 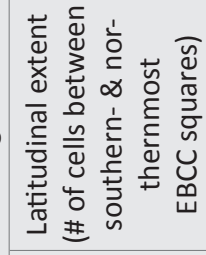 & $\stackrel{m}{-}$ & 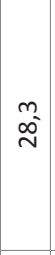 & 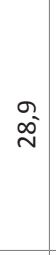 & $\stackrel{m}{\infty} \stackrel{m}{\sim}$ & $\stackrel{m}{\stackrel{m}{N}}$ & 离 & $\begin{array}{l}\tilde{L} \\
\text { c. }\end{array}$ & 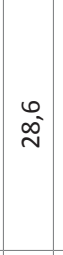 & $\stackrel{+\infty}{\sim}$ & $\stackrel{\substack{0 \\
\sim}}{\sim}$ & 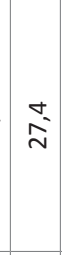 & 今̀ & $\stackrel{m}{m}^{m}$ & î̀ & Oे & $\tilde{c}$ \\
\hline 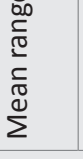 & 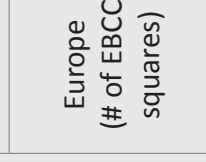 & 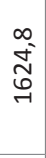 & 点 & \begin{tabular}{l}
$\infty$ \\
\multirow{J}{J}{} \\
$\underset{J}{-}$
\end{tabular} & 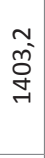 & 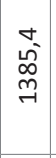 & 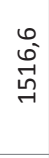 & $\begin{array}{c}\hat{\tilde{D}} \\
\tilde{n} \\
\end{array}$ & 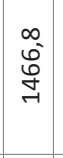 & $\begin{array}{l}\text { 守 } \\
\text { 岁 }\end{array}$ & $\underset{\vec{f}}{\vec{f}}$ & $\mid \begin{array}{c}m \\
\tilde{D} \\
\tilde{m} \\
-1\end{array}$ & 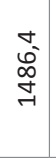 & 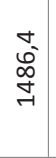 & 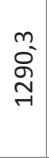 & $\begin{array}{l}0 \\
\overrightarrow{0} \\
\stackrel{-}{\rightarrow}\end{array}$ & $\begin{array}{l}\text { N } \\
\text { Gे } \\
\text { Н̂ }\end{array}$ \\
\hline & 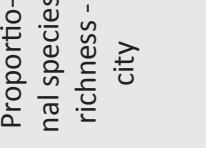 & $\begin{array}{l}\hat{\vec{b}} \\
0^{\circ}\end{array}$ & $\mid$\begin{tabular}{|l}
$\overrightarrow{0}$ \\
$\stackrel{0}{0}$ \\
0
\end{tabular} & $\begin{array}{l}\hat{o} \\
\tilde{m} \\
0\end{array}$ & $\begin{array}{l}\underset{\tilde{m}}{\tilde{m}} \\
\sigma^{2}\end{array}$ & $\mid \begin{array}{c}0 \\
0 \\
m \\
0 \\
0\end{array}$ & $\begin{array}{l}\tilde{m} \\
\text { un } \\
o\end{array}$ & $\begin{array}{l}\hat{o} \\
0 \\
0 \\
0\end{array}$ & 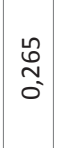 & $\begin{array}{l}\infty \\
\stackrel{\infty}{n} \\
0\end{array}$ & 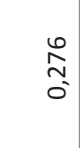 & $\begin{array}{l}\text { L } \\
\text { L̊ } \\
0\end{array}$ & $\begin{array}{c}\vec{m} \\
\overrightarrow{0}\end{array}$ & $\begin{array}{l}\vec{N} \\
\tilde{m} \\
0^{-}\end{array}$ & 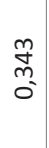 & $\begin{array}{l}\hat{0} \\
0 \\
0\end{array}$ & $\begin{array}{l}-1 \\
0 \\
0 \\
0\end{array}$ \\
\hline & 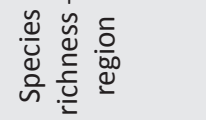 & 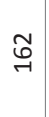 & సి & 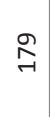 & $\begin{array}{l}\mathscr{\infty} \\
\stackrel{\infty}{\rightarrow-1}\end{array}$ & 岂 & 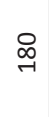 & $\underset{\sim}{\infty}$ & : & $\stackrel{m}{\underset{\sim}{*}}$ & శ్ & : & $\underset{\sim}{\infty}$ & $\underset{\sim}{\infty}$ & $\underset{\sim}{\stackrel{N}{7}}$ & ஓ् & $\vec{\infty}$ \\
\hline & 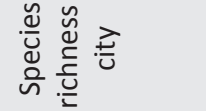 & Оి. & 6 & 㟔 & 8 & $\widetilde{\sigma}$ & $\mathscr{6}$ & $\stackrel{\mathscr{Z}}{\underset{\sim}{*}}$ & $\forall$ & $\infty_{\infty}^{\infty}$ & กn & 省 & in & 8 & ติ & $\overrightarrow{\vec{m}}$ & 吋 \\
\hline & 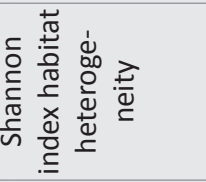 & $\begin{array}{l}\text { o. } \\
\text { : } \\
0\end{array}$ & 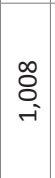 & $\begin{array}{l}\tilde{O}_{0} \\
0 \\
0\end{array}$ & $\begin{array}{l}\text { ָे } \\
\text { i- }\end{array}$ & $\begin{array}{l}\hat{n} \\
\hat{\alpha} \\
0\end{array}$ & 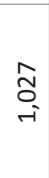 & $\begin{array}{l}\tilde{\tilde{o}} \\
0 \\
-i\end{array}$ & $\begin{array}{l}\text { L } \\
\hat{n} \\
0 \\
0\end{array}$ & $\begin{array}{l}\text { Lू } \\
\text { o. } \\
0\end{array}$ & $\begin{array}{l}\overrightarrow{0} \\
0 \\
0\end{array}$ & $\begin{array}{l}\text { 菋 } \\
\infty \\
0\end{array}$ & 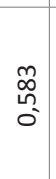 & $\begin{array}{l}\text { Oे } \\
\text { o. } \\
\text { - }\end{array}$ & $\begin{array}{l}\mathbb{J} \\
\$ \\
0^{\prime}\end{array}$ & $\begin{array}{l}\text { fे } \\
\text { o }\end{array}$ & 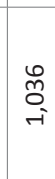 \\
\hline & 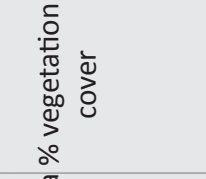 & $\begin{array}{l}\mathfrak{y} \\
\underset{c}{ } \\
0\end{array}$ & $\mid \begin{array}{l}\infty \\
\stackrel{1}{a} \\
0\end{array}$ & 0 & $\begin{array}{l}\infty \\
\stackrel{0}{0} \\
\stackrel{0}{0}\end{array}$ & 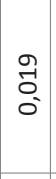 & 告 & $\begin{array}{l}\vec{a} \\
\hat{1} \\
0\end{array}$ & $\begin{array}{l}0 \\
0 \\
0 \\
0\end{array}$ & $\begin{array}{l}\vec{m} \\
\overrightarrow{0} \\
\overrightarrow{0}\end{array}$ & 0 & \begin{tabular}{l}
0 \\
\multirow{2}{0}{} \\
0
\end{tabular} & $\begin{array}{l}-1 \\
0 \\
0\end{array}$ & $\begin{array}{l}\text { बे } \\
\overrightarrow{0} \\
0\end{array}$ & $\begin{array}{l}\text { थू } \\
\text { Oे }\end{array}$ & 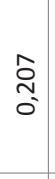 & 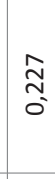 \\
\hline & 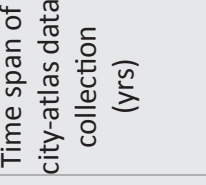 & $m$ & in & $\theta$ & $N$ & $N$ & ণ & in & $N$ & เn & $N$ & ㅇ & $N$ & $N$ & $\stackrel{\sim}{\sim}$ & 아 & $\stackrel{2}{N}$ \\
\hline & 总 & $\vec{m}$ & $\begin{array}{l}\mathfrak{z} \\
\hat{\exists}\end{array}$ & $\stackrel{\omega}{m}$ & 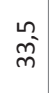 & $\stackrel{+}{\stackrel{N}{N}}$ & $\stackrel{?}{\text { }}$ & 䒚 & $\stackrel{n}{\stackrel{n}{N}}$ & $\stackrel{\substack{\infty \\
m}}{\infty}$ & $\overrightarrow{\mathfrak{y}}$ & $\mid \begin{array}{c}\overrightarrow{0} \\
\vec{\sim}\end{array}$ & $\begin{array}{l}\stackrel{0}{1} \\
\underset{f}{*}\end{array}$ & in & $\begin{array}{l}\text { n̂. } \\
\text { ğ }\end{array}$ & $\begin{array}{l}0 \\
\infty \\
\vec{d} \\
\forall\end{array}$ & $\begin{array}{l}m \\
\text { f } \\
\text { f́ }\end{array}$ \\
\hline & 营 & $\begin{array}{l}\tilde{N} \\
\text { ñ }\end{array}$ & $\mid \begin{array}{c}m \\
\infty \\
0 \\
q \\
q\end{array}$ & 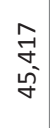 & $\begin{array}{l}\infty \\
0 \\
\vec{y} \\
\dot{g}\end{array}$ & 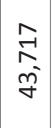 & 志 & $\begin{array}{l}0 \\
0 \\
0 \\
0 \\
i n\end{array}$ & 胥 & $\begin{array}{l}\vec{q} \\
\vec{\forall}\end{array}$ & $\begin{array}{l}\tilde{m} \\
\hat{\varrho} \\
\stackrel{y}{q}\end{array}$ & $\hat{\tilde{y}}$ & 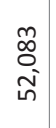 & $\begin{array}{l}\stackrel{\sim}{N} \\
\underset{n}{n}\end{array}$ & 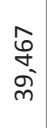 & 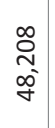 & $\stackrel{\sim}{\sim}$ \\
\hline & $\begin{array}{l}\frac{0}{0} \\
\frac{1}{3} \\
\text { to } \\
0 \\
0\end{array}$ & $\begin{array}{c}\stackrel{m}{m} \\
\infty^{\infty}\end{array}$ & \begin{tabular}{l}
$\stackrel{N}{\sim}$ \\
\multirow{J}{\sim}{}
\end{tabular} & $\begin{array}{l}\hat{0} \\
\infty \\
-7 \\
\overrightarrow{7}\end{array}$ & $\begin{array}{l}\stackrel{2}{7} \\
\sigma\end{array}$ & $\stackrel{+}{\circ}$ & $\begin{array}{l}\hat{~} \\
\text { - } \\
\end{array}$ & 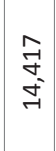 & $\begin{array}{l}0 \\
0 \\
0 \\
0 \\
\vdots\end{array}$ & $\stackrel{\stackrel{n}{\sim}}{\stackrel{\sim}{\sim}}$ & 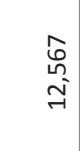 & $\begin{array}{l}\stackrel{m}{m} \\
\tilde{m} \\
\sim \\
\sim\end{array}$ & \begin{tabular}{l}
$\hat{a}$ \\
0 \\
\multirow{n}{*}{}
\end{tabular} & 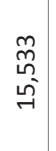 & $\begin{array}{l}\hat{0} \\
m \\
i^{\prime}\end{array}$ & $\begin{array}{l}\stackrel{m}{n} \\
\stackrel{n}{-1}\end{array}$ & $\begin{array}{l}\overrightarrow{1} \\
\text { ì } \\
\text { in }\end{array}$ \\
\hline & E्ञ & 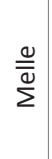 & $\mid \begin{array}{l}\frac{0}{0} \\
\frac{0}{02} \\
\frac{10}{2}\end{array}$ & $\begin{array}{l}0 \\
\frac{0}{0} \\
\frac{0}{0} \\
0\end{array}$ & $\sum_{\frac{\pi}{0}}^{\frac{\pi}{2}}$ & $\stackrel{\frac{\pi}{2}}{\underline{a}}$ & 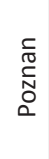 & 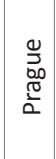 & 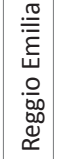 & $\begin{array}{l}\stackrel{\varpi}{E} \\
\stackrel{0}{\circ} \\
\check{x}\end{array}$ & 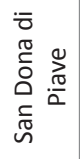 & 茜 & 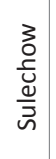 & $\begin{array}{l}\frac{5}{N} \\
0 \\
0 \\
\frac{0}{0} \\
3 \\
n\end{array}$ & 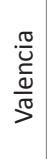 & $\begin{array}{l}\stackrel{0}{0} \\
\stackrel{5}{0} \\
\stackrel{N}{>}\end{array}$ & $\begin{array}{l}3 \\
0 \\
0 \\
\frac{n}{w 0} \\
3\end{array}$ \\
\hline
\end{tabular}




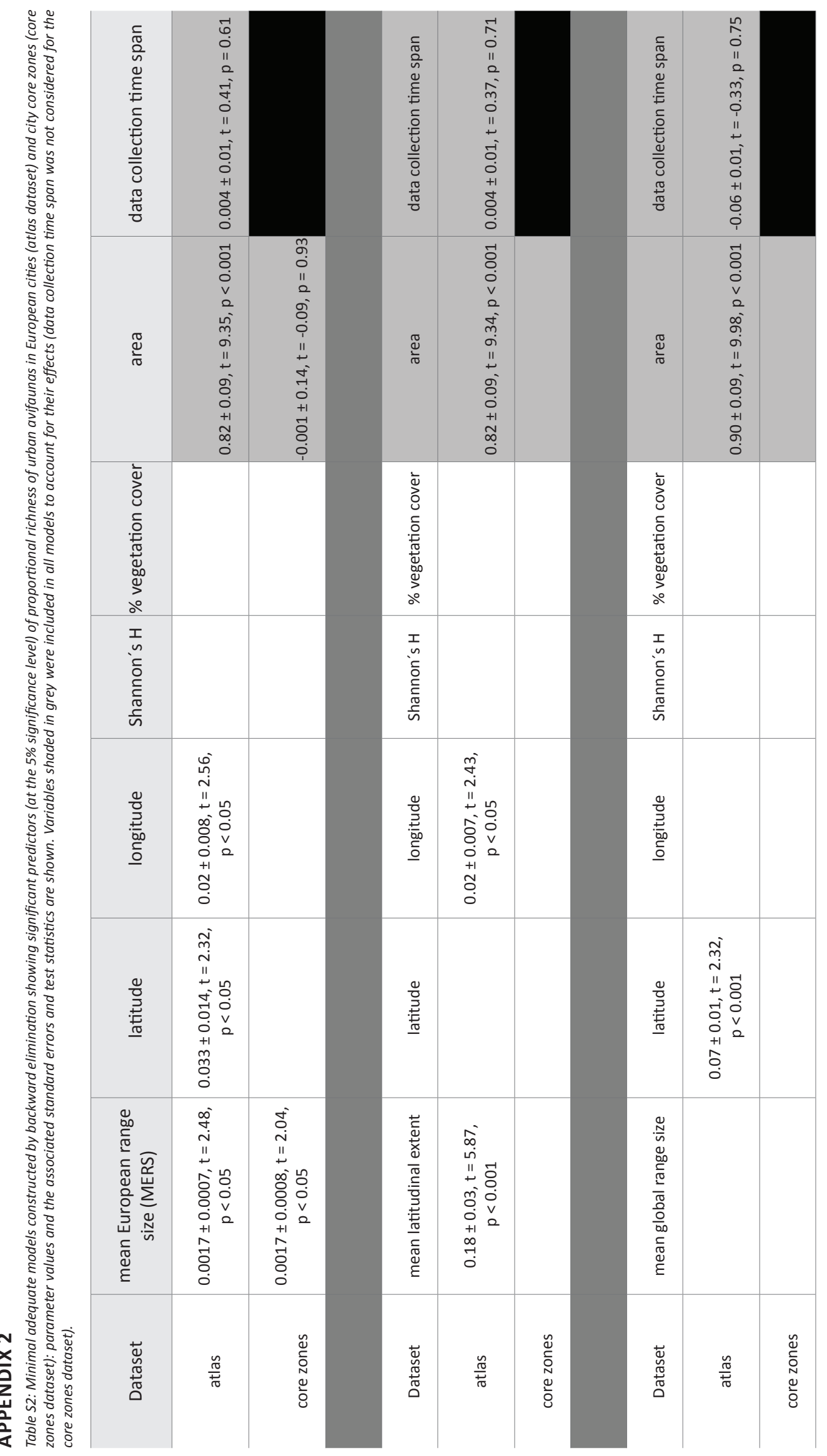




\section{APPENDIX 3}
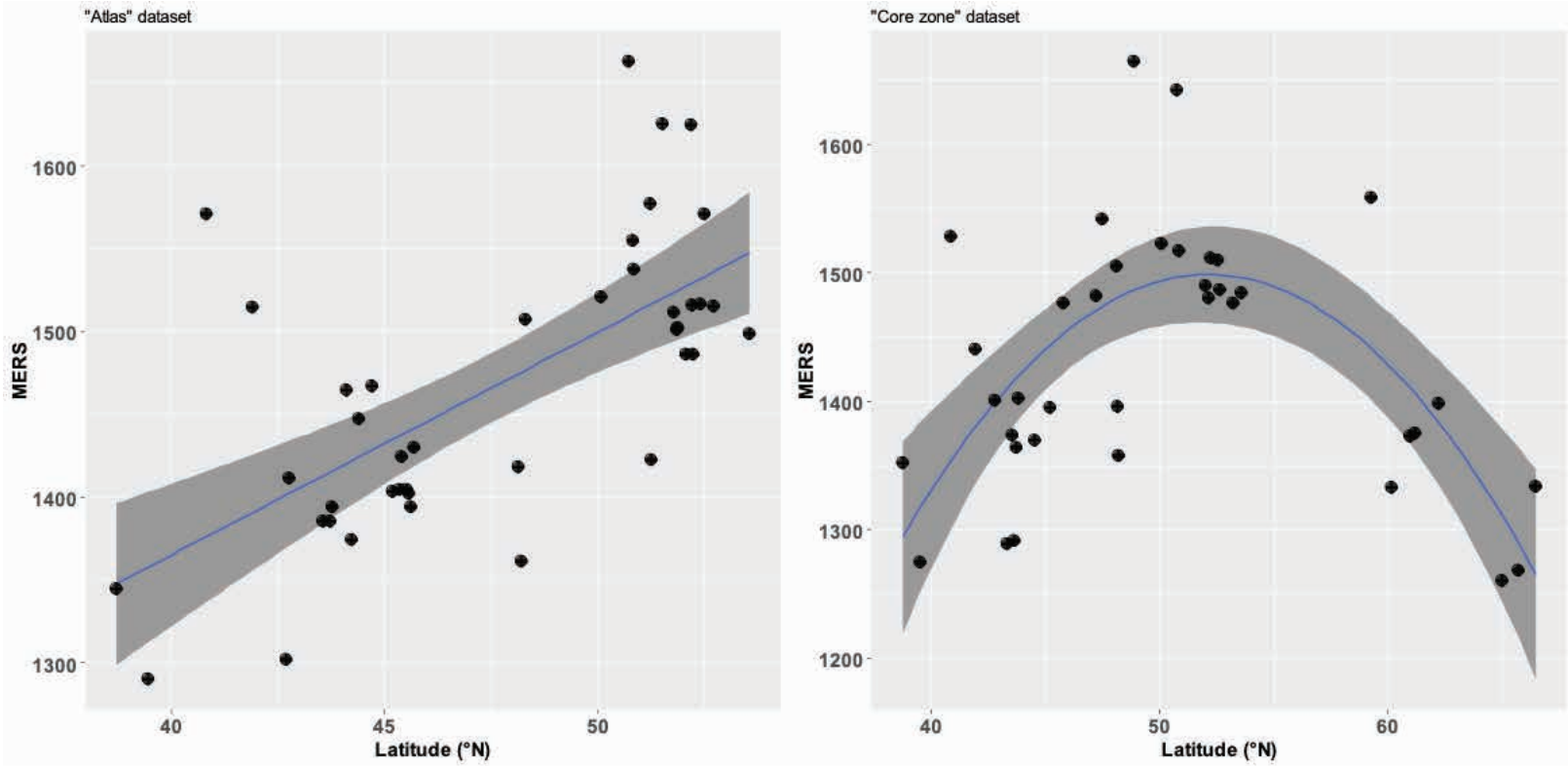

Fig. S3.1: Mean European range size (MERS) of birds in regional assemblages (defined as nine EBCC grid cells around each city) plotted against latitude a) atlas dataset $\left(R^{2}{ }_{A D J}=0.42, p<0.001\right) ;$ b) core zone dataset $\left(R_{A D J}^{2}=0.43, p<0.001\right)$. Trends fitted by OLS regression, shaded area depicts $95 \%$ confidence intervals.
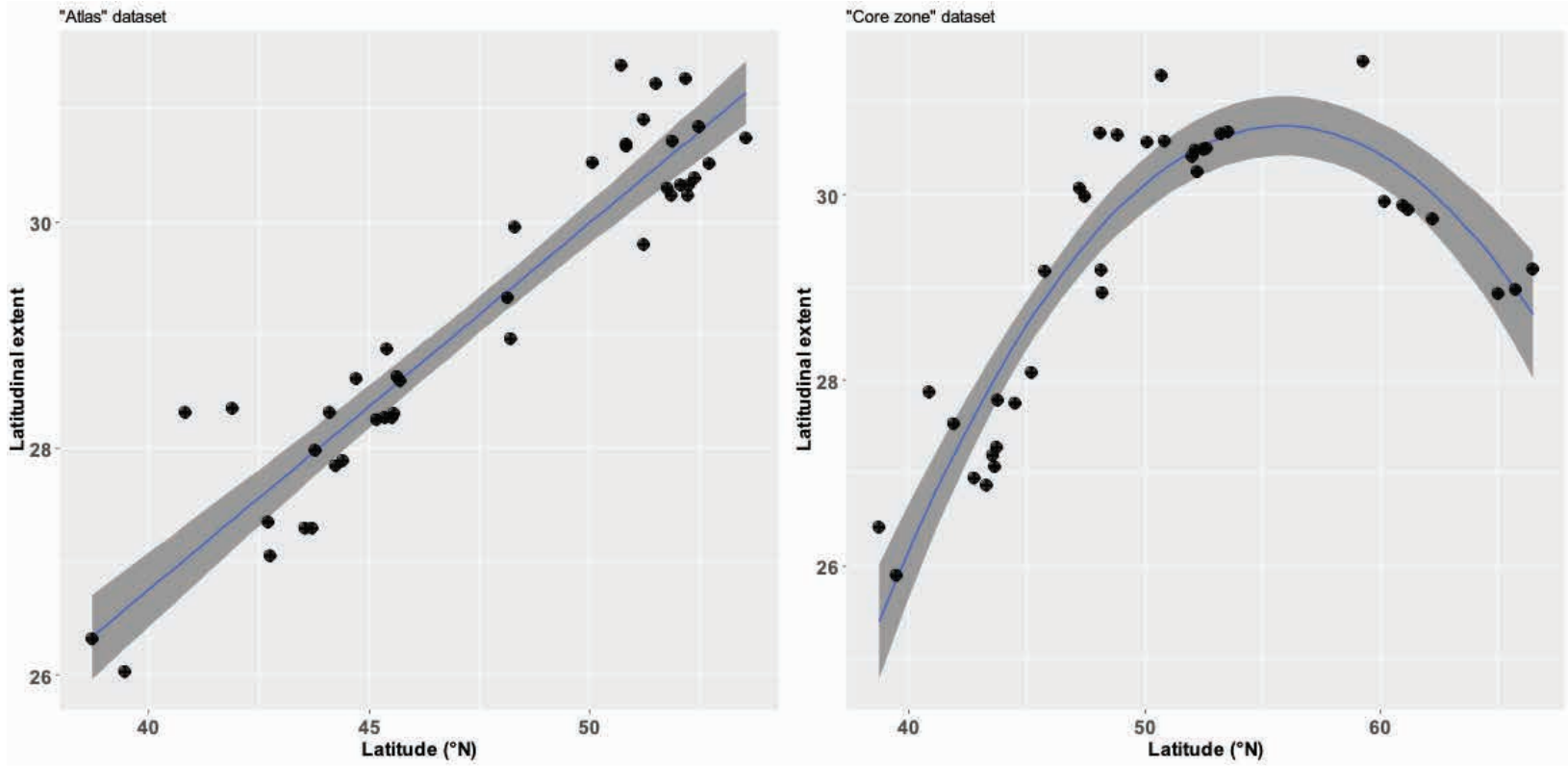

Fig. S3.2: Mean latitudinal extent (defined as the number of cells between the southernmost and northernmost occupied EBCC atlas grid cells) of birds in regional assemblages (defined as nine EBCC grid cells around each city) plotted against latitude: a) atlas dataset $\left(R^{2}=0.88, p<0.001\right.$ ) b) core zone dataset $\left(R_{A D J}^{2}=0.83, p<0.001\right)$. Trends fitted by OLS regression, shaded area depicts $95 \%$ confidence intervals. 

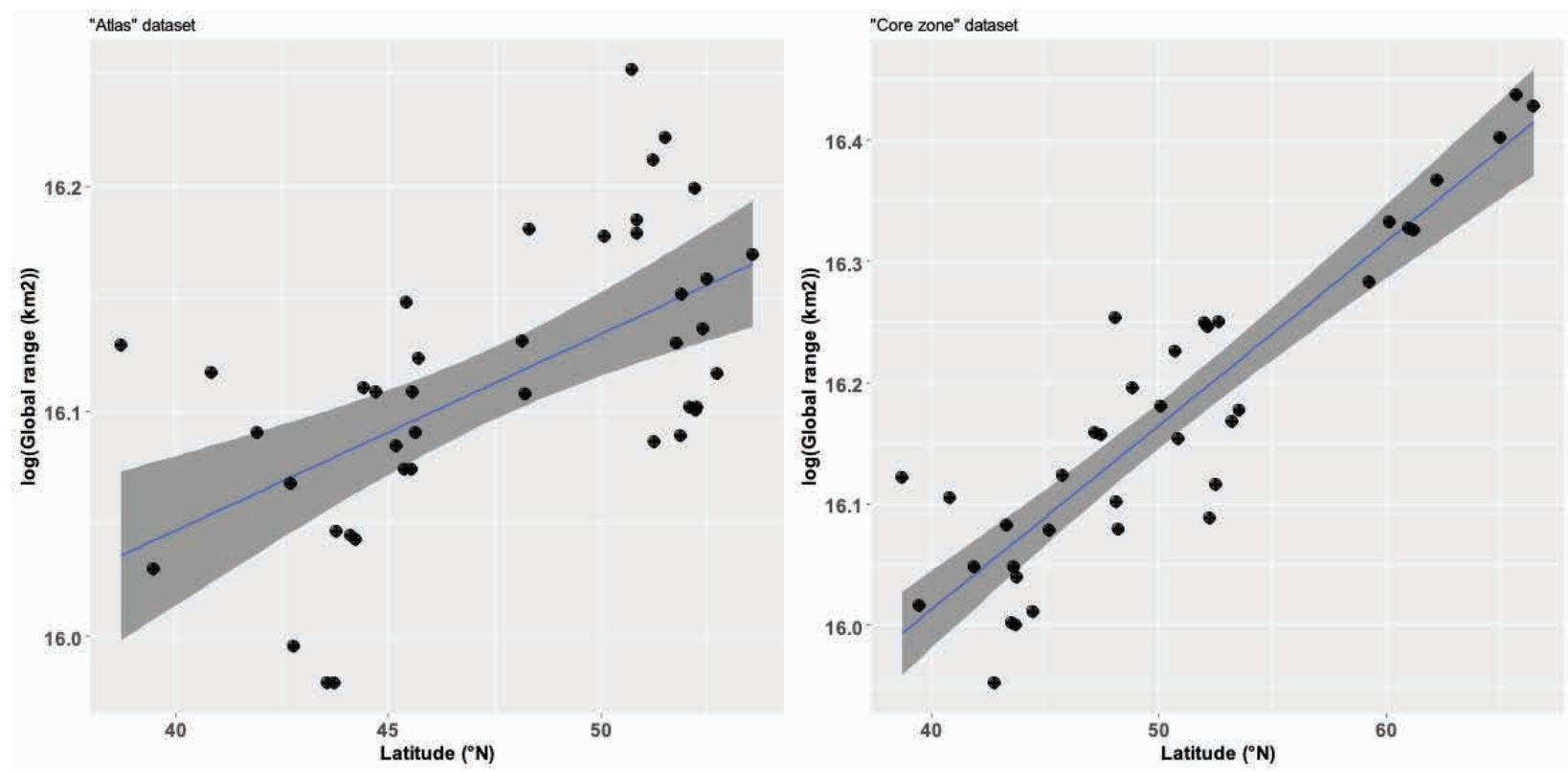

Fig. S3.3: Mean global range size of birds in regional assemblages (defined as nine EBCC grid cells around each city) plotted against latitude: a) atlas $\operatorname{dataset}\left(R_{A D J}^{2}=0.34, p<0.001\right) ;$ b) core zone dataset $\left(R_{A D J}^{2}=0.81, p<0.001\right)$. Trends fitted by OLS regression, shaded area depicts $95 \%$ confidence intervals.
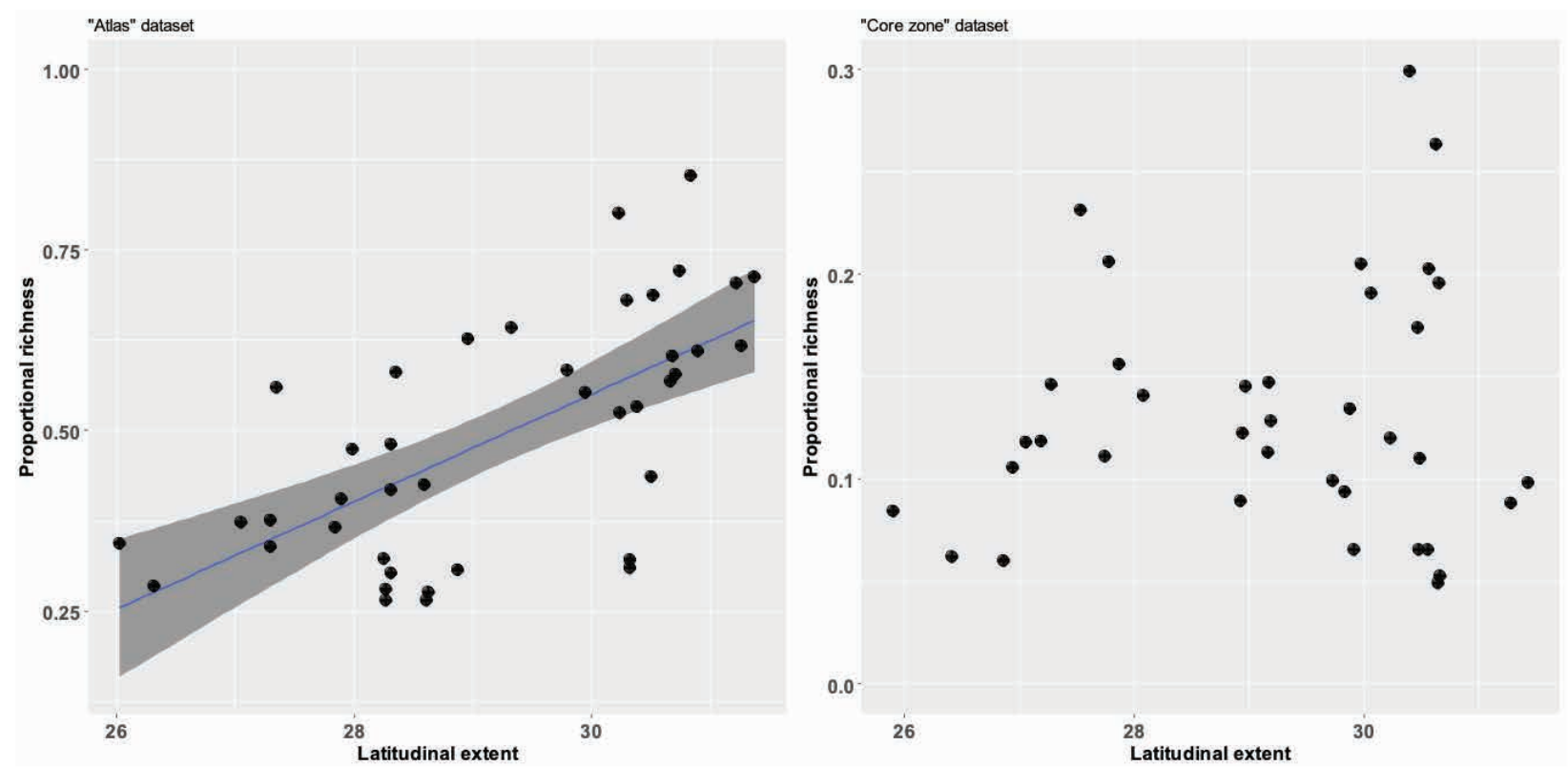

Fig. S3.4: Relationship between the proportional richness of European urban avifaunas (a) atlas dataset $\left(R^{2}=0.42, p<0.001\right)$; b) core zone dataset $\left(R_{A D J}^{2}=-0.016, p=0.51\right)$ ) plotted against the mean latitudinal extent (defined as the number of cells between the southernmost and northernmost occupied EBCC atlas grid cells) of species of particular regional assemblages. The trend was fitted by OLS regression, shaded area depicts $95 \%$ confidence intervals. 

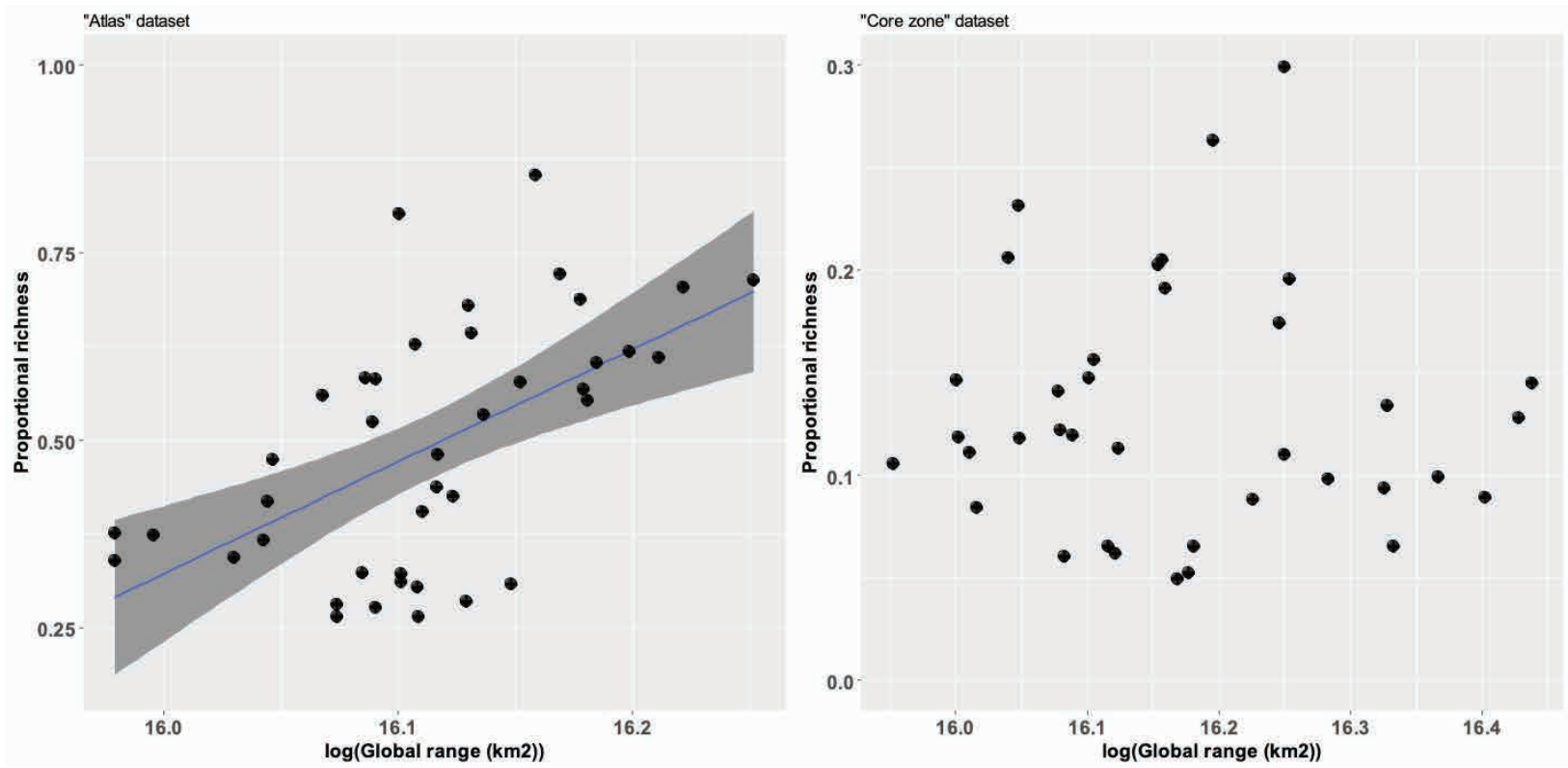

Fig. S3.5: Relationship between the proportional richness of European urban avifaunas (a) atlas dataset $\left.\left(R_{A D J}^{2}=0.30, p<0.001\right) ; b\right)$ core zone dataset $\left(R_{A D J}^{2}=-0.028, p\right.$ $=0.86)$ ) plotted against the mean global range size (II-transformed) of species of particular regional assemblages. The trend was fitted by OLS regression, shaded area depicts $95 \%$ confidence intervals. 